Research Journal of Applied Sciences, Engineering and Technology 17(1): 1-6, 2020

DOI: $10.19026 /$ rjaset.17.6027

ISSN: 2040-7459; e-ISSN: 2040-7467

(C) 2020 Maxwell Scientific Publication Corp.

Submitted: May 13, 2019

Accepted: August 7, 2019

Published: February 15, 2020

\title{
Research Article \\ Pull-out Resistance Parallel to Grain of Threaded Steel Rod Glued-in Glubam with Edge Distance Variation
}

\author{
Karyadi, Bela Prayogo, Nindyawati and Prijono Bagus Susanto \\ Department of Civil Engineering, Faculty of Engineering, Universitas Negeri Malang, \\ Malang, 65145, Indonesia
}

\begin{abstract}
This study aimed to obtain the pull-out resistance parallel to the grain of the threaded steel rod glued-in glubam with various edge distances. The wood structures, both for connection and for reinforcement, used glued-in rods connection. However, there was no research on the application of glued-in-rod into the connection of structural elements from glued laminated bamboo (glubam) due to lack of information on the basic characteristics of the glued-in rod on laminated bamboo. This experiment tested the pull-out resistance and stiffness of the threaded steel rod bounded parallel to the grain in laminated bamboo with varying edge distances. The dimension of laminated bamboo specimens were $100 \times 100 \times 100 \mathrm{~mm}$, the threaded steel rod diameter was $10 \mathrm{~mm}$, the drill hole diameter was $14 \mathrm{~mm}$ and this research used sikadur 732 as the adhesive. This experiment made eight various edge distances: 1d; $1.5 \mathrm{~d} ; 2 \mathrm{~d} ; 2.5 \mathrm{~d} ; 3 \mathrm{~d} ; 3.5 \mathrm{~d} ; 4 \mathrm{~d}$; and $4.5 \mathrm{~d}$, with $\mathrm{d}$ as the threaded steel rod diameter and made five replicas of each variation. The results showed that the $3 \mathrm{~d}$ edge distance or greater had the constant pull-out resistance while less than $3 \mathrm{~d}$ edge distance had less pull-out resistance. The slip modulus for the threaded steel rod glued-in glubam in this study was not influenced by edge distance with a range $3.732 \mathrm{kN} / \mathrm{mm}$ to $7.768 \mathrm{kN} / \mathrm{mm}$.
\end{abstract}

Keywords: Edge distance, laminated bamboo, pull out resistance, slip modulus, threaded steel

\section{INTRODUCTION}

There are numerous researches on glued laminated bamboo (glubam) application for construction. The researches included beam and column structural elements (Xiao et al., 2010; Sinha et al., 2014; Karyadi and Susanto, 2017; Karyadi et al., 2018).

Assembling structural elements into building structures require a connection using various shapes and materials. Recently, there was a development of a glued-in rod connector and its application in wood structure; both for connector (Gonzalez et al., 2016; O'Neill et al., 2017; Gattesco et al., 2010) or reinforcement (Steiger et al., 2015; Harte et al., 2015).

However, there was no study in glued-in rod applications on the connection of laminated bamboo structural element. The reason were due to the lack of information on the base characteristic of glued-in rod in laminated bamboo. Research by Yan et al. (2016) offered information about the effect of the depth and diameter of the glued-in rod on the pull-out strength. Nonetheless, it left many unresearched parameters. Therefore, this research aimed to study the distance effect between the threaded steel rod and the edge of laminated bamboo on the threaded steel rod pull-out resistance, slip modulus and types of failure.

Researchers have developed formulas to calculate the pull-out resistance of glued-in rod application in wood material. The formula developed by Steiger et al. (2006), Yeboah et al. (2013) and Yan et al. (2016) is usefull to calculate the glued-in rod pull-out resistance with edge distance greater than or equal to the allowed minimum distance. Generally, Stepinac et al. (2013) concluded that there are three main parameters involved in the above formula, e.g., the diameter of the glued-in rod, glued-in length and interfacial layer shear strength between wood and glue or between glue and rod. Similar to the conclusion above, Stepinac et al. (2013) and Yan et al. (2016) formulated the Eq. (1):

$$
F=L_{a} \times \pi \times d_{a} \times f_{v}
$$

With

F : Glued-in rod pull-out resistance

$\mathrm{L}_{\mathrm{a}}$ : Glued-in length

$\mathrm{d}_{\mathrm{a}} \quad$ : Diameter of the rod

$\mathrm{f}_{\mathrm{v}} \quad$ : Interfacial shear strength

$\pi \quad$ : Mathematical constant

Corresponding Author: Karyadi, Department of Civil Engineering, Faculty of Engineering, Universitas Negeri Malang, Malang, 65145, Indonesia

This work is licensed under a Creative Commons Attribution 4.0 International License (URL: http://creativecommons.org/licenses/by/4.0/). 


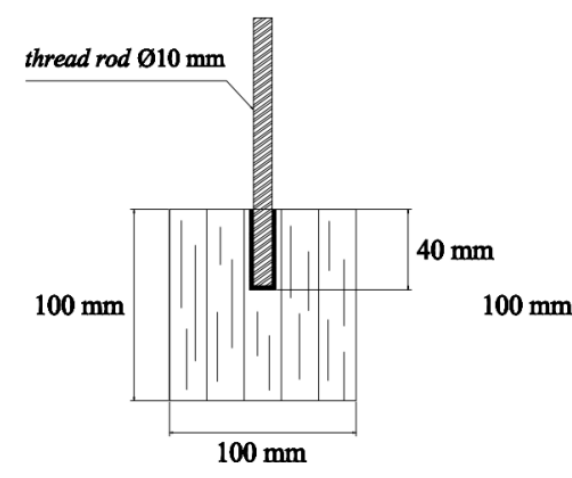

(a)

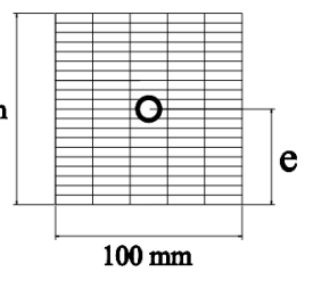

(b)

Fig. 1: Specimen; (a) Side view and (b) Cross section; e is the edge distance

Deng (1997) and New Zealand Timber Design Guide (NZW 14085 SC, 2007) developed another formula that including the distance between the gluedin rod and the edge of the timber displayed in the Eq. (2):

$$
Q_{k}=C d \cdot k_{b} \cdot k_{e} \cdot k_{m}(l / d)^{0.86} \cdot(d / 20)^{1.62} \cdot(h / d)^{0.5} \cdot(e / d)^{0.5}
$$

Within the Eq. (2); Qk: pull-out resistance $(\mathrm{N}),(\mathrm{kN}), \mathrm{k}_{\mathrm{b}}$, $\mathrm{ke}_{\mathrm{e}} \mathrm{km}$ : bar type factor, epoxy factor, moisture factor respectively, l: glued-in length $(\mathrm{mm})$, d: diameter of steel $\operatorname{rod}(\mathrm{mm}), \mathrm{h}$ : diameter of the drill hole $(\mathrm{mm})$, e: edge distance $(\mathrm{mm}), \mathrm{Cd}=8.54$ for Deng (1997) formula and $\mathrm{Cd}=6.73$ for New Zealand Timber Design Guide (NZW 14085 SC, 2007).

The amount of slip during pull-out resistance were also crucial to note. This parameter is vital to determine the connection rigidity using the glued-in rod as stated in the slip modulus $\left(\mathrm{K}_{\mathrm{s}}\right)$, calculated with the formula of (BS EN 26891, 1991):

$$
K_{s}=\frac{0.4 F_{\max }}{4 / 3\left(d_{04}-d_{01}\right)}
$$

With,

$\mathrm{K}_{\mathrm{s}} \quad$ : Slip modulus $(\mathrm{kN} / \mathrm{mm})$

$\mathrm{F}_{\max }$ : Maximum load $(\mathrm{kN})$

$\mathrm{d}_{04}:$ Slip at $40 \% \mathrm{~F}_{\max }(\mathrm{mm})$

$\mathrm{d}_{01}$ : Slip at $10 \% \mathrm{~F}_{\text {max. }}(\mathrm{mm})$

\section{MATERIALS AND METHODS}

This research obtained 3-5 years old Asian bamboo (Dendrocalamus asper Backer) Malang, East Java, Indonesia. Then, cut and split them into $5 \times 20 \mathrm{~mm}$ in cross-section and $1 \mathrm{~m}$ in length strips. Soaked the bamboo strips in a mixture solution of $1 \%$ boric acid $\left(\mathrm{H}_{3} \mathrm{BO}_{3}\right)$ and $1 \%$ borax $\left(\mathrm{Na}_{2} \mathrm{~B}_{4} \mathrm{O}_{2}\right)$ and dried. Glued the strips with less than $12 \%$ moisture content into each other using $268 \mathrm{~g} / \mathrm{m}^{2}$ urea-formaldehyde adhesive and cool-pressed in $2 \mathrm{MPa}$ for four hours (Karyadi and Susanto, 2017). After, reaped the materials. Cut the

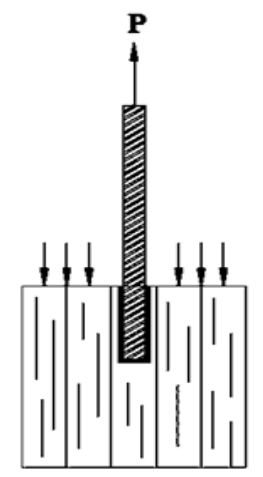

(a)

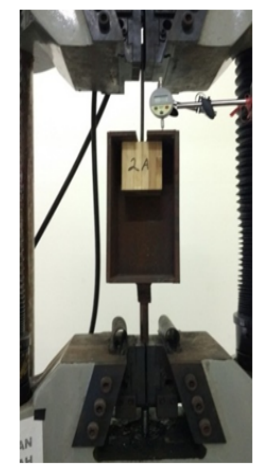

(b)
Fig. 2: Experimental setting up; (a) Testing configuration and (b) Photo of testing

laminated bamboo into $100 \mathrm{~mm} \times 100 \mathrm{~mm} \times 100 \mathrm{~mm}$ dimensions and drilled $14 \mathrm{~mm}$ diameter and $40 \mathrm{~mm}$ depth. The varying distances between the drill holes of the laminated bamboo edge were $1 \mathrm{~d}, 1.5 \mathrm{~d}, 2 \mathrm{~d}, 2.5 \mathrm{~d}, 3 \mathrm{~d}$, $3.5 \mathrm{~d}, 4 \mathrm{~d}, 4.5 \mathrm{~d}$; where $\mathrm{d}$ was the diameter of threaded steel rod with five replicas for each variation. The threaded steel rod with $\mathrm{f}_{\mathrm{y}}=350 \mathrm{MPa}$ in $10 \mathrm{~mm}$ diameter and $250 \mathrm{~mm}$ length then put into drill holes. Before, gave the adhesive epoxy type in sikadur 732 brand (Fig. 1) in the drill hole.

This research used the Universal Testing Machine (UTM) with $1000 \mathrm{kN}$ capacity and $0.1 \mathrm{kN}$ precision to test the pull-out resistance and the dial gauge with 10 $\mathrm{mm}$ capacity and $0.01 \mathrm{~mm}$ precision to find the amount of the slip during the test. Figure 2 displays the test set up using loading configuration pull-compression.

This study used the Eq. (4) and (5) to calculate the amount of slip:

$$
\Delta S=Y-\Delta L
$$

Calculating $\Delta \mathrm{L}$ used the formula:

$$
\Delta L=\frac{P \cdot L_{o}}{\Delta S \cdot E}
$$


Res. J. Appl. Sci. Eng. Technol., 17(1): 1-6, 2020

Table 1: Results for pull-out resistance test

\begin{tabular}{|c|c|c|c|c|}
\hline Specimen code & Edge distance (e) $(\mathrm{mm})$ & $\begin{array}{l}\text { Diameter of treaded } \\
\text { rod }(\mathrm{d})(\mathrm{mm})\end{array}$ & $\begin{array}{l}\text { Anchored length (Lo) } \\
(\mathrm{mm})\end{array}$ & $\begin{array}{l}\text { Bounded area }\left(\mathrm{A}_{\mathrm{s}}\right) \\
\left(\mathrm{mm}^{2}\right)\end{array}$ \\
\hline S1-d & 10 & 10 & 40 & 1759 \\
\hline S1.5-d & 15 & 10 & 40 & 1759 \\
\hline S2-d & 20 & 10 & 40 & 1759 \\
\hline $\mathrm{S} 2.5-\mathrm{d}$ & 25 & 10 & 40 & 1759 \\
\hline S3-d & 30 & 10 & 40 & 1759 \\
\hline S3.5-d & 35 & 10 & 40 & 1759 \\
\hline S4-d & 40 & 10 & 40 & 1759 \\
\hline S4.5-d & 45 & 10 & 40 & 1759 \\
\hline Specimen code & $\begin{array}{l}\text { Number of } \\
\text { specimen }\end{array}$ & $\begin{array}{l}\text { Average of Pull-out } \\
\text { resistance }(\mathrm{P}) \mathrm{kN}\end{array}$ & $\begin{array}{l}\text { Standard } \\
\text { deviation } \mathrm{kN}\end{array}$ & $\begin{array}{l}\text { Average of shear } \\
\text { strength }\left(f_{v}\right) \mathrm{MPa}\end{array}$ \\
\hline S1-d & 5 & 13.020 & 0.835 & 7.401 \\
\hline S1.5-d & 5 & 14.720 & 0.915 & 8.367 \\
\hline S2-d & 5 & 16.320 & 1.085 & 9.276 \\
\hline $\mathrm{S} 2.5-\mathrm{d}$ & 4 & 17.400 & 0.483 & 9.890 \\
\hline S3-d & 5 & 19.720 & 1.190 & 11.209 \\
\hline S3.5-d & 4 & 19.400 & 0.864 & 11.027 \\
\hline S4-d & 4 & 18.700 & 0.600 & 10.629 \\
\hline S4.5-d & 4 & 19,325 & 0,665 & 10,985 \\
\hline
\end{tabular}

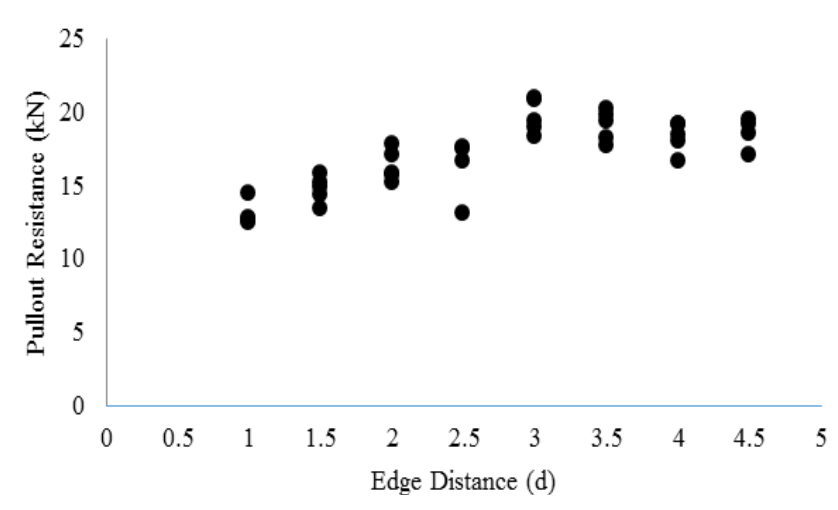

Fig. 3: Relationship between pull-out resistance and edge distance

In Eq. (4) and (5),

$\Delta \mathrm{s} \quad$ : Slip

$\mathrm{Y}$ : Increased total length

E : Modulus of elasticity of threaded steel rod

$\Delta \mathrm{L}$ : Increased length of threaded steel rod

$\mathrm{P} \quad$ : Load

As : Cross-sectional area of threaded steel rod

Lo : Initial threaded steel rod length

\section{RESULTS AND DISCUSSION}

The moisture content on laminated bamboo right after the test was $15.56 \%$ based on ASTM (2003). The Specific Gravity test from laminated bamboo referred to the ASTM (2014) with the result of $0.687 \mathrm{~g} / \mathrm{cm}^{3}$ that was similar to the research of Malanit et al. (2011) with the result of $0.720 \mathrm{~g} / \mathrm{cm}^{3}$. The pull-out resistance test results from threaded steel rod with the varying edge distances of $1 \mathrm{~d}, 1.5 \mathrm{~d}, 2 \mathrm{~d}, 2.5 \mathrm{~d}, 3 \mathrm{~d}, 3.5 \mathrm{~d}, 4 \mathrm{~d}, 4.5 \mathrm{~d}$ obtained the pull-out resistance, the damage types that occurred and slip modulus as explained below.

Threaded steel rod pull-out resistance: In this research, the pull-out resistance results indicated that the minimum distance of threaded steel rod before decreasing the pull-out strength occurred at $3 \mathrm{~d}$ edge distance with the value of $19.72 \mathrm{kN}$ and the shear strength, calculated using Eq. (1), was 11.209 MPa. The similar shear strength value was obtained by Yan et al. (2016), with the result of about $10.54 \mathrm{MPa}$. Table 1 lists the complete results of the pull-out resistance test for all varying edge distance.

At the $2.5 \mathrm{~d}$ edge distance, pull-out resistance and shear strength declined to $17.40 \mathrm{kN}$ and $9.890 \mathrm{MPa}$. The value drops for $11.76 \%$ from $3 \mathrm{~d}$ edge distance. At a $2 \mathrm{~d}$ edge distance or less, the pull-out resistance kept declining as observed from Fig. 3.

The drop in pull-out resistance is caused by the splitting failure that occurred in the specimens before the maximum load in the glued-in rod was achieved. Therefore, the load value is lower compared to the specimen with no splitting failure. Figure 3 shows the correlations between edge distance and pull-out resistance results from the test. Whereas Fig. 4 shows the comparison in pull-out resistance between glued-in rod in laminated bamboo with equation approach of the glued-in rod in wood.

Figure 4 indicates that this research results in pullout resistance were similar to the pull-out resistance calculated using the equation of Deng (1997) and 
Res. J. Appl. Sci. Eng. Technol., 17(1): 1-6, 2020

Table 2: Types of failure

\begin{tabular}{llllll}
\hline & & & & Types of failure \\
Specimen code & $\begin{array}{l}\text { Diameter of treaded } \\
\text { rod (mm) }\end{array}$ & Edge distance (d) & $\begin{array}{l}\text { Number } \\
\text { of specimen }\end{array}$ & Pulled & Splitting \\
\hline S1-d & 10 & 1 & 5 & - & 5 \\
S1.5-d & 10 & 1.5 & 5 & 1 & 4 \\
S2-d & 10 & 2 & 5 & 5 & - \\
S2.5-d & 10 & 2.5 & 5 & 5 & - \\
S3-d & 10 & 3.5 & 5 & 5 & - \\
S3.5-d & 10 & 4 & 5 & 5 & - \\
S4-d & 10 & 4.5 & 5 & 5 & - \\
S4.5-d & 10 & & 5 & & - \\
\hline
\end{tabular}

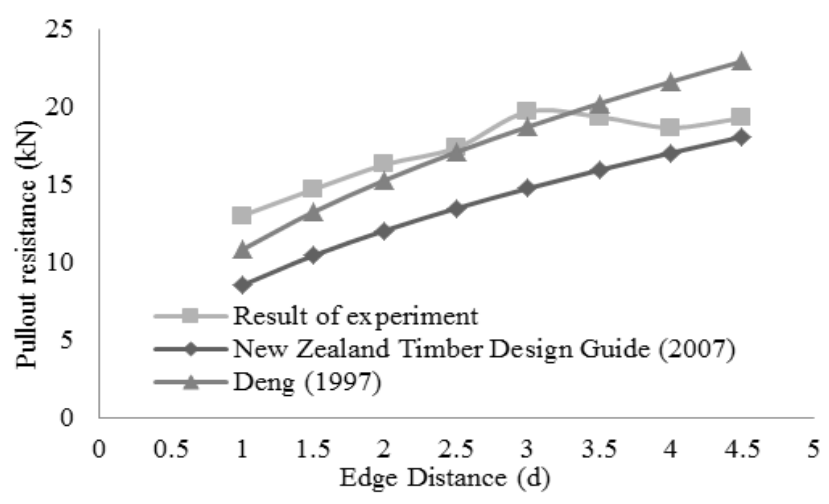

Fig. 4: Comparison on pull-out resistance

higher than the pull-out resistance calculated using the equation of New Zealand Timber Design Guide (NZW 14085 SC, 2007), or Eq. (2). The dissimilarities were the results of material differentiation. This research used laminated bamboo material while Deng (1997) and New Zealand Timber Design Guide (NZW 14085 SC, 2007) used the wood material. Although varied in pull-out resistance, the trendline that occurred shows an almost similar pattern. The similarity shows that increasing edge distances caused an increase in pull-out resistance. Blass and Laskewitz (1999) stated that the minimum steel rod edge distance in wood specimen before pull-out resistance and shear strength declined was at 2.5d; while Steiger et al. (2006) gave $2.3 \mathrm{~d}$ distance.

Types of failure in glued-in rod connection: Based on Table 2, samples with the edge distance less than twice the diameter of the threaded rod experienced splitting failure in the laminated bamboo (Fig. 5b). Samples with the edge distance more than or equal to twice the diameter of the threaded rod experienced damaged, such as pulled threaded rod along with bamboo surfaces around the epoxy adhesive (Fig. 5a). From the damage type that occurred, in summary, the minimum threaded rod distance from the outer edge of laminated bamboo to prevent the splitting failure in laminated bamboo was at twice the diameter from the outer edge laminated bamboo.

Research on pull-out resistance in the glued-in rod of wood by Gattesco et al. (2010) stated that splitting failure is the most frequent damage among others.

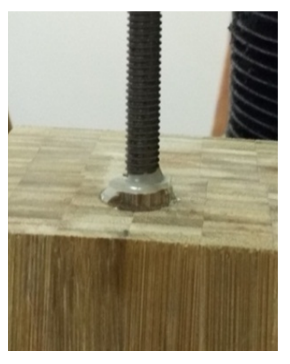

(a)

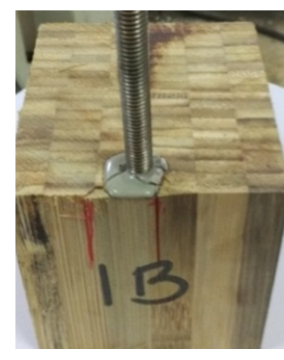

(b)
Fig. 5: Types of failure; (a) Pulled failure and (b) Splitting failure

Preventing this problem requires knowledge on the minimum distance between the steel rod to the specimen's edge. Results from Gattesco et al. (2010) showed that the minimum distance required was 2.3 times the diameter of the steel rod to prevent splitting failure on wood. In this research, the minimum distance required was at $2 \mathrm{~d}$ towards laminated bamboo.

Slip modulus: Pull-out resistance in glued-in rod resulted in a curve between loads $(\mathrm{P})$ and slip $(\Delta \mathrm{S})$ as observed in Fig. 6. Two important things from this figure are the slip modulus and the collapse model.

The almost similar slope shows that the edge distance did not influence the slip modulus from the glued-in rod in this research. In Table 3, the average values of slip modulus calculated by Eq. (3) is between $3.732 \mathrm{kN} / \mathrm{mm}$ to $7.768 \mathrm{kN} / \mathrm{mm}$. Maria and Ianakiev (2015) found that the slip modulus was $1.18 \mathrm{kN} / \mathrm{mm}$ 
Res. J. Appl. Sci. Eng. Technol., 17(1): 1-6, 2020

Table 3: Result of slip modulus

\begin{tabular}{lllllll}
\hline $\begin{array}{l}\text { Edge distance } \\
(\mathrm{e})(\mathrm{mm})\end{array}$ & $\begin{array}{l}\text { Threaded rod } \\
\text { diameter }(\mathrm{d}) \\
(\mathrm{mm})\end{array}$ & $\begin{array}{l}\text { Anchored length } \\
(\mathrm{mm})\end{array}$ & $\begin{array}{l}\text { Initial length } \\
(\mathrm{Lo})(\mathrm{mm})\end{array}$ & $\begin{array}{l}\text { Maximum pull- } \\
\text { out load } \\
(\mathrm{P}) \mathrm{kN}\end{array}$ & $\begin{array}{l}\text { Slip at max. pull- } \\
\text { out load }(\Delta \mathrm{S}) \\
(\mathrm{mm})\end{array}$ & $\begin{array}{l}\text { Slip modulus } \\
\left(\mathrm{K}_{\mathrm{s}}\right) \mathrm{kN} / \mathrm{mm}\end{array}$ \\
\hline 10 & 10 & 40 & 153.0 & 13.020 & 2.251 & 5.681 \\
15 & 10 & 40 & 149.6 & 14.720 & 2.325 & 5.308 \\
20 & 10 & 40 & 150.4 & 16.320 & 2.585 & 7.768 \\
25 & 10 & 40 & 151.8 & 17.400 & 2.780 & 7.197 \\
30 & 10 & 40 & 151.4 & 19.720 & 3.321 & 5.229 \\
35 & 10 & 40 & 151.2 & 19.400 & 3.034 & 5.313 \\
40 & 10 & 40 & 150.6 & 18.700 & 2.920 & 3.732 \\
45 & 10 & 40 & 150.0 & 19.325 & 2.879 & 4.029 \\
\hline
\end{tabular}

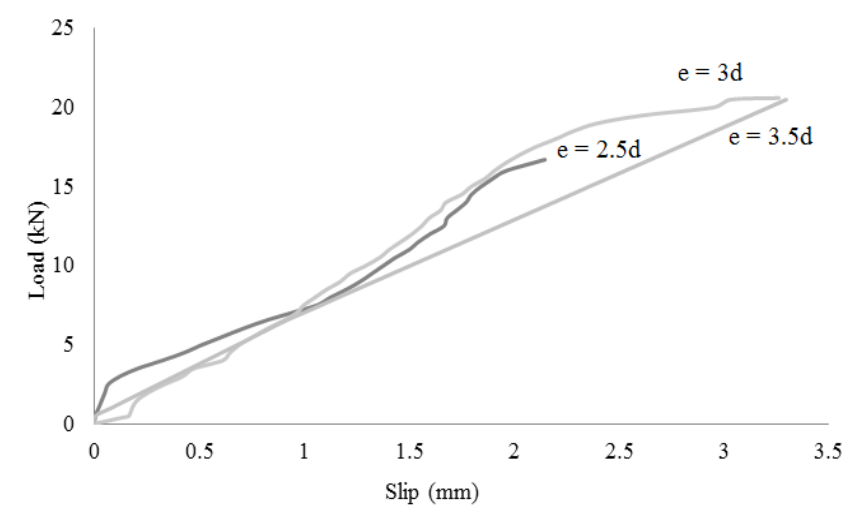

Fig. 6: Relationship between load and slip

for a glued-in rod in $60 \mathrm{~mm}$ anchored length in Douglas Fir Wood. Verdet et al. (2016) tested glued-in rod with epoxy adhesive (Sikadur 330, Sika, Le Bourger, Switzerland) and timber glulam produced from Black Spruce at $20^{\circ} \mathrm{C}$ temperature resulted in slip modulus of $108 \mathrm{kN} / \mathrm{mm}$. Rossignon and Espion (2008) tested glued-in rod in glulam $160 \mathrm{~mm}$ anchored length in Norway Spruce with epoxy adhesive and obtained the initial modulus of $94.6 \mathrm{kN} / \mathrm{mm}$. The main parameter that caused the varieties in the slip modulus from this research and the other mentioned research above was the embedment length, the material and the adhesive that was used.

In this research, the sudden drop of glued-in rod ability to resist the loads identified the brittle failure, as seen in Fig. 6. This type of collapse occurred due to interfacial damage between glue and bamboo that eliminate interfacial shear strength. Gonzalez et al. (2016) discovered that glued-in rod with embedment length 7.5 times the diameter of rod experienced a brittle failure, while rod with 10 times diameter embedment experienced a ductile failure. Maria and Ianakiev (2015) found that brittle failure occurred in pull-out resistance of $8 \mathrm{~mm}$ diameter glued-in rod in an Oak Timber and Douglas Fir Timber with embedment length $60 \mathrm{~mm}$.

\section{CONCLUSION}

Conclusions from this research were as below:

- A minimum distance of threaded steel rod from the outer edge laminated bamboo before experiencing a decline of pull-out resistance was at $3 \mathrm{~d}$, with $\mathrm{d}$ was diameter threaded steel rod.

- $\quad$ The splitting failure on laminated bamboo occurred when the edge distance of threaded steel rod was less than $2 \mathrm{~d}$, whereas the distance of the threaded steel rod was more than or equal to $2 \mathrm{~d}$, the pulled failure of threaded steel rod from laminated bamboo occurred.

- The edge distance did not influence the magnitude of the slip modulus on the threaded steel rod gluedin laminated bamboo.

- The brittle failure occurred in a threaded steel rod glued-in laminated bamboo that experienced splitting or pulled failure.

\section{ACKNOWLEDGMENT}

This study was a part of fundamental research funded by The Ministry of Research, Technology and Higher Education of The Republic of Indonesia 2018.

\section{CONFLICT OF INTEREST}

There's no conflict of interest.

\section{REFERENCES}

ASTM (American Society for Testing and Materials), 2003. Standard Test Methods for Direct Moisture Content Measurement of Wood and Wood-Base Materials. Annual Book of ASTM Standards, Vol. 04:10: D 4442-92 Section 2, West Conshohocken, PA, United States. 
ASTM (American Society for Testing and Material), 2014. Standard Test Methods for Density and Specific Gravity (Relative Density) of Wood and Wood-Based Materials. Annual Book of ASTM Standards, Vol. 04:10: D 2395-14 Section 6, West Conshohocken, PA, United States.

Blass, H.J. and B. Laskewitz, 1999. Effect of spacing and edge distance on the axial strength of glued-in rods. Proceeding of the CIB-W18 Meeting ThirtyTwo, Graz, Austria, Aug. 23-25, Paper 32-7-12.

BS EN 26891, 1991. Timber Structures-Joints Made with Mechanical Fasteners-General Principles for the Determination of Strength and Deformation Characteristics. European Committee for Standardisation (CEN), Brussels, Belgium.

Deng, J.X., 1997. Strength of epoxy bonded steel connections in glue laminated timber. Ph.D. Thesis, Department of Civil Engineering, University of Canterbury, Christchurch, New Zealand.

Gattesco, N., A. Gubana and M. Buttazzi, 2010. Pullout strength of bar glued-in-timber joints. Proceeding of 11 th Word Conference on Timber Engineering (WCTE). Trentino, Italy, Jun. 20-24, pp: 1194-1200.

Gonzalez, E., C. Avez and T. Tannert, 2016. Timber joints with multiple glued-in steel rods. J. Adhesion, 92(7-9): 635-651.

Harte, A., R. Jockwer, M. Stepinac, T. Descamps, V. Rajcic and P. Dietsch, 2015. Reinforcement of timber structures - the route to standardization. Proceeding of 3rd International Conference on Structural Health Assessment of Timber Structures. Wroclaw - Poland, Sep. 9-11, pp: 78-88.

Karyadi and P.B. Susanto, 2017. Mechanical characteristics of box-section beam made of slicedlaminated Asian bamboo (Dendrocalamus asper) in bending failure mode under transversal load. Proceeding of AIP Conference, American Institute of Physics, Vol. 1887, ID: 020062.

Karyadi, S.M. Dewi and A. Soehardjono, 2018. The strength of axially loaded square hollow-section column made of laminated Asian bamboo (Dendrocalamus asper becker). Res. J. Appl. Sci. Eng. Technol., 15(9): 337-343.

Malanit, P., M.C. Barbu and A. Frühwald, 2011. Physical and mechanical properties of oriented strand lumber made from an Asian bamboo (Dendrocalamus asper backer). Eur. J. Wood Wood Prod., 69(1): 27-36.
Maria, V.D. and A. Ianakiev, 2015. Adhesive connections in timber: A comparison between rough and smooth wood bonding surfaces. Int. J. Chem. Mol. Nucl. Mater. Metallurgical Eng., 9(3): 395-401.

NZW 14085 SC, 2007. New Zealand Timber Design Guide. Timber Industry, Federation Inc., Wellington, New Zealand.

O’Neill, C., D. McPolin, S.E. Taylor, A.M. Harte, C. O'Ceallaigh and K.S. Sikora, 2017. Timber moment connections using glued-in basalt FRP rods. Constr. Build. Mater., 145: 226-235.

Rossignon, A. and B. Espion, 2008. Experimental assessment of the pull-out strength of single rods bonded in glulam parallel to the grain. Holz Roh Werkst., 66: 419-432.

Sinha, A., D. Way and S. Mlasko, 2014. Structural performance of glue laminated bamboo beams. J. Struct. Eng., 140(1): 04013021.1-04013021.8.

Steiger, R., E. Gehri and R. Widmann, 2006. Pull-out strength of axially loaded steel rods bonded in glulam parallel to the grain. Mater. Struct., 40: 6978.

Steiger, R., E. Serrano, M. Stepinac, V. Rajčić, C. O'Neill, D. McPolin and R. Widmann, 2015. Strengthening of timber structures with glued-in rods. Constr. Build. Mater., 97: 90-105.

Stepinac, M., F. Hunger, R. Tomasi, E. Serrano, V. Rajcic and J.W. van de Kuilen, 2013. Comparison of design rules for glued-in rods and design rule proposal for implementation in European standards. Proceeding of CIB - W18 Meeting 46, Vancouver (Canada), Aug. 26-29, pp: 1-13.

Verdet, M., A. Salenikovich, A. Cointe, J.L. Coureau, P. Galimard, W.M. Toro, P. Blanchet and C. Delisee, 2016. Mechanical performance of polyurethane and epoxy adhesives in connections with glued-in rods at elevated temperatures. BioResources, 11(4): 8200-8214.

Xiao, Y., Q. Zhou and B. Shan, 2010. Design and construction of modern bamboo bridge. J. Bridge Eng., 15(5): 533-541.

Yan, Y., H. Liu, X. Zhang and Y. Huang, 2016. The effect of depth and diameter of glued-in rods on pull-out connection strength of bamboo glulam. J. Wood Sci., 62: 109-115.

Yeboah, D., S. Taylor, D. McPolin and R. Gilfillan, 2013. Pull-out behaviour of axially loaded Basalt Fibre Reinforced Polymer (BFRP) rods bonded perpendicular to the grain of glulam elements. Constr. Build. Mater., 38(5): 962-969. 